\title{
ANALISIS PERBANDINGAN QUALITY OF SERVICE (QOS) FIRMWARE ORIGINAL TL-WR841ND DENGAN FIRMWARE OPENWRT BERBASIS OPEN SOURCE
}

\author{
Muh. Syarif Hidayatullah ${ }^{1)}$, Kusnawi $^{2)}$ \\ 1), 2) Teknik Informatika STMIK AMIKOM Yogyakarta \\ Jl Ring road Utara, Condongcatur, Sleman, Yogyakarta 55281 \\ muh.hidayatullah@students.amikom.ac.id ${ }^{1)}$, khusnawi@amikom.ac.id ${ }^{2)}$
}

\begin{abstract}
Abstrak
Perangkat wireless yang sering digunakan adalah $T L-W R 841 N D$, tipe tersebut memiliki fitur konfigurasi yang lengkap serta harga yang terjangkau. Permasalahan yang sering terjadi pada perangkat access point TL-WR84IND adalah firmware original TL-WR84IND kurang stabil dan sering stuck sehingga harus direstart ulang dengan mencabut kabel power kemudian dipasang kembali, Koneksi internet pasti terputus sehingga hal ini sangat mengganggu saat user sedang mengakses internet. Salah satu alternative solusi adalah mengupgrade firmware original access point atau wireless router menjadi firmware yang bersifat opensource yang embedded pada access point atau wireless router yaitu Openwrt.

Penelitian ini akan membantu mengetahui apakah memasang OpenWRT pada perangkat wireless $T L$ WR841ND ini akan membuat QoS jaringan wireless menjadi lebih baik, sama, atau lebih buruk dari default firmware sehingga nantinya hasil dari penelitian ini diharapkan akan berguna bagi para pengguna OpenWRT atau yang akan menggunakan OpenWRT
\end{abstract}

Kata kunci: Wireless, QoS, Firmware, Openwrt, Default, TL-WR84IND
Abstract
Wireless device that is often used is the $T L$ - WR841ND, the type of features the complete configuration and an affordable price. Problems often occur on the access point TL-WR84IND is the original firmware $T L$-WR84IND less stable and often stuck so it should be restarted by unplugging the power cable and then reassembled, definitely interrupted internet connection so it is very disturbing when a user is accessing the Internet. One alternative solution is the original firmware upgrade access point or wireless router into open source firmware that is embedded in the access point or wireless router that is OpenWRT. This study will help determine whether to install OpenWRT on wireless devices TL-WR84IND will make QoS wireless networks become better, same,

or worse than the default firmware so that later the results of this study are expected to be useful for those users OpenWRT or who will use OpenWRT Keywords: Wireless, QoS, Firmware, OpenWRT, Default, TL-WR84IND

\section{Pendahuluan}

Berkembangnya jaringan nirkabel, maka banyak perusahaan-perusahaan yang bergerak di bidang penyedia alat-alat jaringan mengeluarkan produk mereka untuk menunjang atau mengiringi perkembanga jaringan nirkabel tersebut. Salah satu vendor yang sangat familiar dengan penguna jaringan nirkabel atau wifi di Indonesia adalah TPLink. Produk-produk dari TP-Link hampir memasuki semua lapisan masyarakat pengguna internet. Apalagi hal itu diperkuat dengan salah satu penyedia jasa internet (ISP) yaitu Speedy yang selalu menggunakan produk TP-Link bagi konsumen mereka. Wireless router yang dikeluarkan oleh TP-Link sangat beragam versinya. Baik itu versi yang memiliki fitur standar sampai versi yang memiliki fitur yang sangat komplek atau lengkap. Salah satu versi wireless router yang mempunyai fitur yang lengkap yaitu TP-Link TL-WR841ND.

Banyaknya perangkat wireless router yang beredar, maka berkembang pula firmwarefirmware yang dapat ditanamkan ke dalam perangkat wireless router. Salah satu firmware yang popular karena memiliki fitur konfigurasi yang lengkap selain itu berbasis open source yaitu OpenWRT. Banyak pendapat yang beredar di kalangan pengguna wireless router bahwa penggunaan OpenWRT dapat meningkatkan kinerja dari perangkat wireless router. selain itu penggunaan OpenWRT juga dapat memberikan keleluasaan pagi pengguna untuk memasang aplikasi lainnya pada perangkat wireless router mereka seperti i-radio, captive portal, sms, ip camera dan lain-lain yang dimana fitur-fitur tersebut tidak akan bisa dipasang pada firmware default. 
Pada penelitian ini akan dilakukan perbandingan antara firmware default dengan firmware OpenWRT apakah benar dapat meningkatkan kinerja dari peragkat wireless router. Analisa kineja yang diambil adalah menggunakan QoS (Quality of Service) dan menggunakan perangkat wireless router TP-Link TL-WR841ND. Berdasarkan latar belakang masalah maka dapat didefinisikan rumusan masalah yaitu:

Bagaimana menganalisis perbandingan QoS (Quality Of Service) pada TL-WR841ND antara menggunakan default firmware dan openWRT dengan mengukur parameter throughput, delay, paket loss, dan jitter?

\section{KAJIAN LITERATUR}

\section{II.1 QoS (Quality of Service)}

\section{II.1.1 Delay}

Menurut Darmawan, Erristhya. Dkk (2012), Delay dalam sebuah proses transmisi paket dalam sebuah jaringan komputer disebabkan karena adanya antrian yang panjang, atau mengambil route lain untuk menghindari kemacetan pada routing. Untuk mencari delay pada paket yang ditransmisikan dengan membagi antara panjang paket (satuan bit) dibagi dengan link bandwidth (satuan bit/s). Untuk mengukur delay pada suatu jaringan komputer menggunakan perintah ping, dimana time pada hasil perintah ping menunjukkan delay pada paket yang dikirimkan.

\begin{tabular}{lc} 
Tabel 1. Standarisasi Delay Versi TIPHON \\
\hline \hline KATEGORI & BESAR DELAY \\
LATENCY & \\
\hline \hline Sangat bagus & $<150 \mathrm{~ms}$ \\
Bagus & $150 \mathrm{~s} / \mathrm{d} 300 \mathrm{~ms}$ \\
Sedang & $\mathrm{s} / \mathrm{d} 450 \mathrm{~ms}$ \\
Jelek & $>450 \mathrm{~ms}$ \\
\hline \hline
\end{tabular}

\section{II.1.2 Jitter}

Jitter adalah variasi dari delay atau selisih antara delay pertama dengan delay selanjutnya. Jumlah toleransi jitter dalam jaringan dipengaruhi oleh kedalaman dari buffer jitter dalam peralatan jaringan. Jika buffer jitter tersedia lebih banyak, maka jaringan dapat mereduksi efek dari jitter (Darmawan, Erristhya. Dkk. 2012).

\begin{tabular}{ll} 
Tabel 2. Standarisasi Jitter Versi TIPHON \\
\hline \hline KATEGORI & NILAI JITTER \\
DEGRADASI & \\
\hline \hline Sangat bagus & $<0 \mathrm{~ms}$ \\
Bagus & $0 \mathrm{~s} / \mathrm{d} 75 \mathrm{~ms}$ \\
Sedang & $76 \mathrm{~s} / \mathrm{d} 125 \mathrm{~ms}$ \\
Jelek & $\mathrm{s} / \mathrm{d} 225 \mathrm{~ms}$ \\
\hline \hline
\end{tabular}

\section{II.1.3 Packet Loss}

Secara umum terdapat empat kategori penurunan performansi jaringan berdasarkan nilai packet loss sesuai dengan versi TIPHONTelecomunications and Internet Protocol Harminization Over Networks (Joesman, 2008 dalam Fantoni 2011), yaitu seperti tampak pada tabel 3 .

\section{II.1.4 Throughput}

Menurut panayleite (2010) bahwa kamampuan throughput dalam menopang hardware (peragkat keras) disebut dengan bandwith. Throughput adalah bandwidth aktual yang terukur pada satuan ukuran waktu tertentu dalam mentransmisikan berkas. Throughput lebih mengambarkan bandwidth yang sebenarnya pada suatu waktu dan pada kondisi jaringan tertentu yang digunakan untuk mengunduh suatu file dengan ukuran tertentu

Tabel 3. Standarisasi Packet Loss versi TIPHON

\begin{tabular}{cc}
\hline \hline KATEGORI DEGREDASI & BESAR PACKET LOSS \\
\hline \hline Sangat bagus & 0 \\
Bagus & $3 \%$ \\
Sedang & $15 \%$ \\
Jelek & $25 \%$ \\
\hline \hline
\end{tabular}

\section{II.2 Perbandingan}

Analisis perbandingan digunakan untuk membandingkan rata-rata antara dua atau lebih sekelompok sampel data. Asumsi mendasar dalam analisis perbandiingan adalah bahwa variable data yang akan dibandingkan harus mengikuti distribusi normal.

Menurut Nazir (2005: 58) penelitian komparatif adalah sejenis penelitian deskriptif yang ingin mencari jawaban secara mendasar tentang sebab-akibat, dengan menganalisisfaktorfaktor penyebab terjadinya ataupun munculnya suatu fenomena tertentu atau penelitian yang bersifat membandingkan.

\section{II.3 OpenWRT}

Menurut Russel (2012:13), Openwrt adalah sebuah proyek opensource untuk menciptakan sebuah sistem operasi gratis yang bisa di install (embedded) pada perangkat radio wireless. Karena dibuat dengan menggunakan kernel Linux maka Openwrt bisa disebut sebagai salah satu distro Linux untuk perangkat embedded (embedded devices).

\section{II.4 Wi-Fi (Wireless Fidelity)}

Menurut Mulyanta (2005:52), WiFi sebenarnya merupakan merek dagang wireless LAN yang diperkenalkan dan distandarisasi oleh WiFi Alliance Standar didasarkan pada standar 802.11. WiFi Alliance pertama kali membentuk Wireless Ethernet Compatibility Alliance 
(WECA), sebuah organisasi nonprofit yang mempunyai fokus pada pemasaran serta mengurusi interoperabilitas pada produk wireless LAN 802.11. WiFi adalah standar IEEE 802.11x, yaitu teknologi wireless atau nirkabel yang mampu menyediakan akses internet dengan bandwidth besar, mencapai 11 Mbps (untuk standar 802.11b).

\section{II.5 Jaringan Komputer}

Interkonektor antara 2 komputer autonomus atau lebih, menggunakan protocol komunikasi yang terhubung dengan media transmisi kabel atau tanpa kabel (wireless) untuk keperluan komunikasi data (Ariyus, Andri K.R. 2008). Menurut wahana computer jaringan computer adalah sekelompok komputer otonom yang saling berhubungan antara satu dengan lainnya menggunakan protocol komunikasi melalui media komunikasi sehingga dapat saling berbagi informasi, program-program, penggunaan bersama perangkat keras seperti printer, hardisk dan sebagainya.

\section{Pembahasan}

\section{III.1 Topologi Jaringan}

Adapun topologi jaringan yang digunakan dalam penelitian ini adalah topologi Star, dibangun dengan menggunakan 3 buah laptop dan 2 buah wireless router. Ketiga buah laptop ini digunakan untuk membangun jaringan yang berbasis client server, satu buah laptop sebagai server dan dua buah laptop akan menjadi client. Semua laptop akan saling terkoneksi dengan menggunakan jaringan WiFi. Adapaun rancangan jaringan $\mathrm{WiFi}$ yang akan digunakan adalah sebagai berikut.

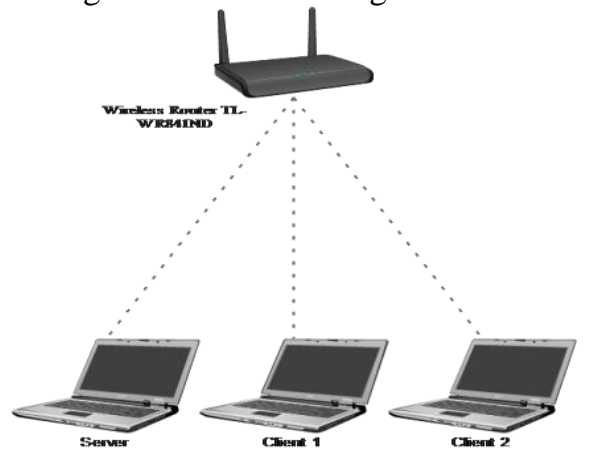

Gambar 1. Rancangan Topologi Jaringan

\section{III.2 Skenario Pengujian}

Pada penelitian ini metode pengujian yang digunakan adalah dengan menggunakan metode skenario yang di buat oleh peneliti. Metode sekenario ini dipilih agar data yang didapatkan sesuai dengan apa yang diharapkan. Oleh sebab itu perlu juga dilakukan perancangan metode penelitian yang meliputi semua aspek atau parameter yang akan diuji dalam hal ini adalah parameter QoS diantaranya throughput, delay, packet loss, dan jitter serta beberapa parameter tambahan seperti jarak dan interferensi atau gangguan dari WiFi lain. Untuk lebih jelasnya dapat dilihat pada gambar berikut.

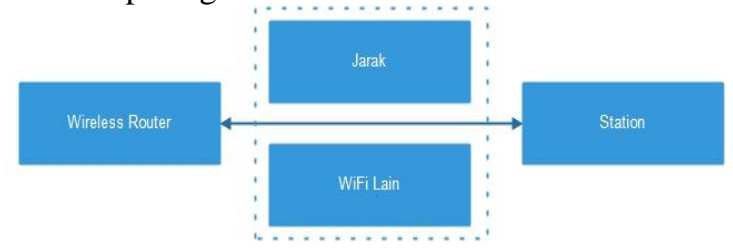

Gambar 2. Skenario Pengujian

\section{III.2.1 Interferensi WIFI}

Konsep yang diterapkan penulis ini mengacu pada interferensi yang terjadi pada jaringan wireless yang dimonitoring menggunakan software wirelessmon, sedangkan untuk pengambilan data parameter QoS menggunakan software jperf. Untuk lebih jelas maka dapat dilihat melalui rancangan logical dari topologi yang akan digunakan saat pengambilan data parameter QoS yang meliputi throughput, delay, jitter, dan packet loss.

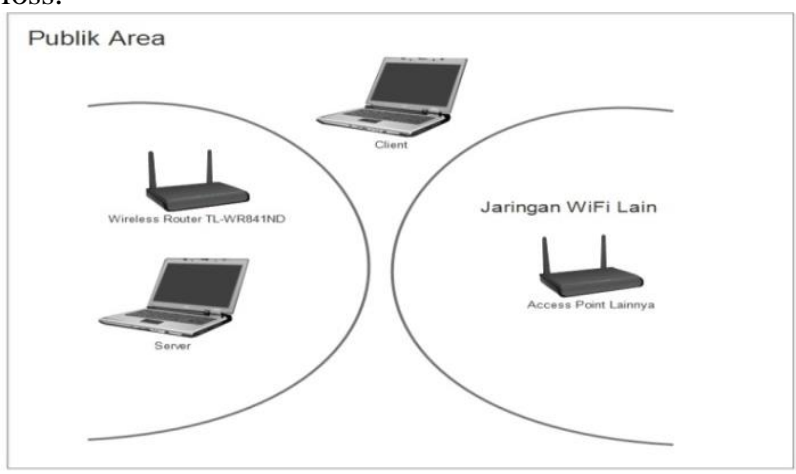

Gambar 3. Interferensi WIFI

Sedangkan ketika melekukan pengujian parameter QoS dimana jaringan wifi tanpa adanya interferensi akan dilakukan pada loss area dalam hal ini tanah lapang yang diamana sedikit terdapat interferensi yang bisa menggangu performa jaringan.

\section{III.2.2 Jarak Pengujian}

Pengujian parameter QoS yang dievaluasi menggunakan parameter tambahan jarak ini bertujuan untuk mengetahui sejauh mana performa dari wireless router yang menggunakan firmware Default dan firmware OpenWRT. Jarak pengujian yang akan digunakan adalah 10 dan 25 meter dari wireless router. Nantinya laptop yang berguna sebagai server dan client akan diletakkan sejauh 10 dan 25 meter dari wireless router baik itu yang 
menggunakan Default firmware maupun OpenWRT. Untuk lebih jelas mengenai jarak yang digunakan dapat dilihat pada gambar berikut.

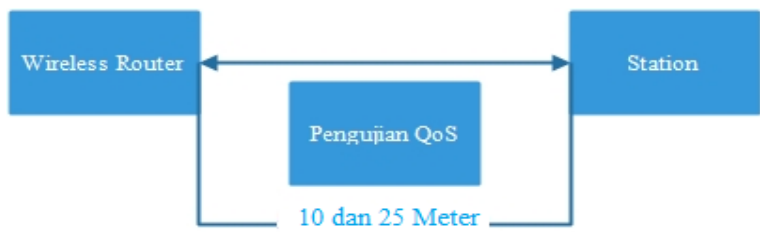

Gambar 4. Jarak Pengujian

\section{III.2.3 Proses dan Tahap Pengambilan Data}

Adapaun tahap dalam pengambilan datanya sebagai berikut.

1. Melakukan konfigurasi jaringan wireless yang dibangun menggunakan wireless router TLWR841ND yang menggunkan Default firmware dan menggunakan OpenWRT

2. Melakukan pengambilan data pada 2 wilayah yang berbeda yaitu wilayah WIFI dan wilayah NON WIFI. Wilayah wifi yang digunakan adalah basement gedung unit 3 STMIK Amikom Yogyakarta, kemudian melakukan pengukuran tiap-tiap parameter QoS berupa throughput, delay, jitter, dan packet loss dari jarak yang berbeda.

3. Proses pengambilan data menggunakan aplikasi jperf untuk throughput, delay, jitter, dan packet loss. Pada tiap-tiap jarak dilakuan pengujian sebanyak 5 kali. Jadi total pengujian yang dilakukan sebayak 20 kali pada area WiFi dan Non WiFi dan itu berlaku pada wireless router yang menggunakan Default firmware maupun OpenWRT. Untuk lebih jelas mengenai pengujian yang akan dilakukan dapat dilihat pada table 4 .

Tabel 4. Skenario Pengujian

\begin{tabular}{|c|c|c|c|}
\hline Percobaan & Lokasi & Jarak & $\begin{array}{c}\text { Wireless } \\
\text { Router }\end{array}$ \\
\hline $1-5$ & Area & 10 & \multirow{3}{*}{$\begin{array}{c}\text { TL- } \\
\text { WR841ND } \\
\text { dengan } \\
\text { Default } \\
\text { Firmware }\end{array}$} \\
\hline $6-10$ & WIFI & 25 & \\
\hline $\begin{array}{l}11-15 \\
16-20\end{array}$ & $\begin{array}{c}\text { Area NO } \\
\text { WIFI }\end{array}$ & & \\
\hline $21-25$ & Area & 10 & \multirow{4}{*}{$\begin{array}{c}\text { TL- } \\
\text { WR841ND } \\
\text { dengan } \\
\text { OpenWRT }\end{array}$} \\
\hline $26-30$ & WIFI & 25 & \\
\hline $30-35$ & & 10 & \\
\hline $36-40$ & $\begin{array}{c}\text { Area NO } \\
\text { WIFI }\end{array}$ & 25 & \\
\hline
\end{tabular}

\section{III.3 Pengujian Throughput}

Pada tahapan ini akan dilakukan analisa perbandingan antara throughput TL-WR841ND dengan Default Firmware dan dengan OpenWRT dalam kondisi area dan jarak pengujian yang berbeda. Berikut grafik pengujian yang dilakukan pada area NO WIFI.

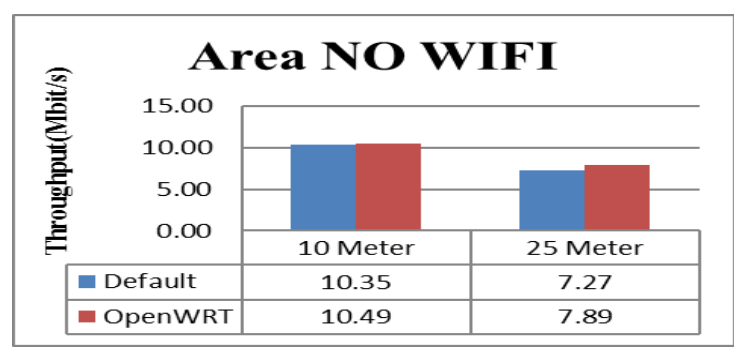

Gambar 5. Pengujian Thoroughput Area NO Wifi

Pada grafik diatas diketahui bahwa pada jarak pengujian 10 meter yang dilakukan pada area NO WIFI ternyata TL-WR841ND yang di custom dengan OpenWRT menghasilkan nilai throughput yang lebih baik dibandingkan dengan Default Firmware. Saat jarak pengujian ditambah menjadi 25 meter terjadi penurunan nilai throughput pada masing-masing firmware.

Secara keseluruhan pengujian throughput yang dilakukan pada area NO WIFI antara Default firmware dan OpenWRT ternyata menghasilkan data bahwa OpenWRT jauh lebih baik dari pada Default firmware.

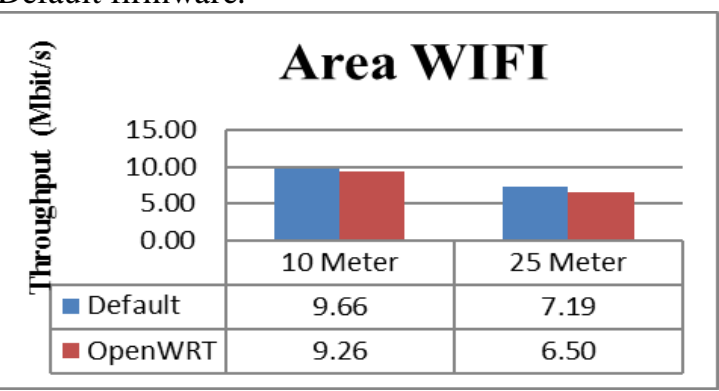

Gambar 6. Pengujian Throughput Area WIFI

Pada grafik diatas justru dapat dilihat bahwa hasil pengujian justru berlawanan dengan pengujian throughputyang dilakukan pada area NO WIFI. Dari kedua grafik pengujian throughput diatas ternyata menghasilkan nilai throughput yang bervariasi antara Default firmware dengan OpenWRT. Dalam kondisi area No WIFI OpenWRT menawarkan throughput yang lebih baik dari pada Default firmware, sebaliknya pada pengujian yang dilakukan pada area WIFI justru OpenWRT menawarkan throughput yang lebih kecil dari pada Default Firmware.

\section{III.4 Pengujian Jitter}

Sama dengan tahapan sebelumnya dimana dilakukan analisa perbandingan throughput terhadap TL-WR841ND dengan Default firmware dan OpenWRT. Pada tahapan ini juga akan dilakukan analisa perbandingan jitter terhadap 
kedua firmware tersebut. Berikut merupakan grafik perbandingan jitter saat pengujian dilakukan pada area NO WIFI.

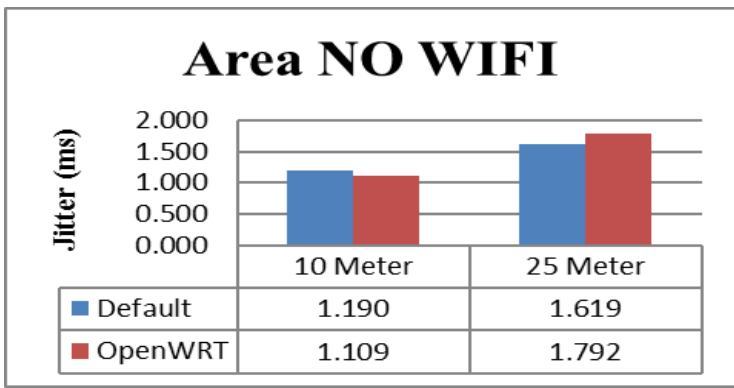

Gambar 7. Pengujian Jitter Area NO WIFI

Hasil jitter yang didapat berdasarkan grafik tersebut masuk ke kategori jitter yang baik. Meskipun ada sedikit perbedaan pada setiap nilai jitter yang didapat selama pengujian yang disebabkan karena adanya pertambahan jarak dalam pengujian. Selanjutnya untuk pengujian jitter yang dilakukan pada area WIFI untuk mengetahui pengaruh interferensi wifi terhadap QoS.

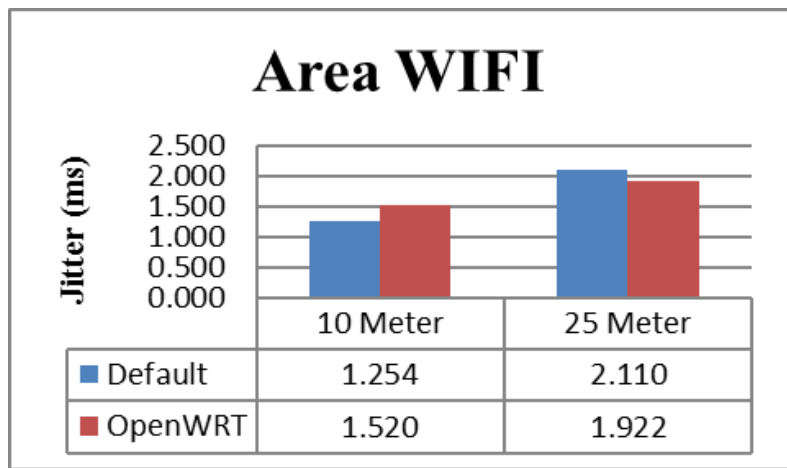

Gambar 8. Pengujian Jitter Area WIFI

\section{III.5 Pengujian Packet Loss}

Pada pengujian packet loss ini tidak banyak data angka bisa dibandingkan, pengujian packet loss ini secara keseluruha menghasilakan packet loss pada angka $0 \%$. Berikut meruapakan data yang didapat selama pengujian packet loss pada area NO WIFI.

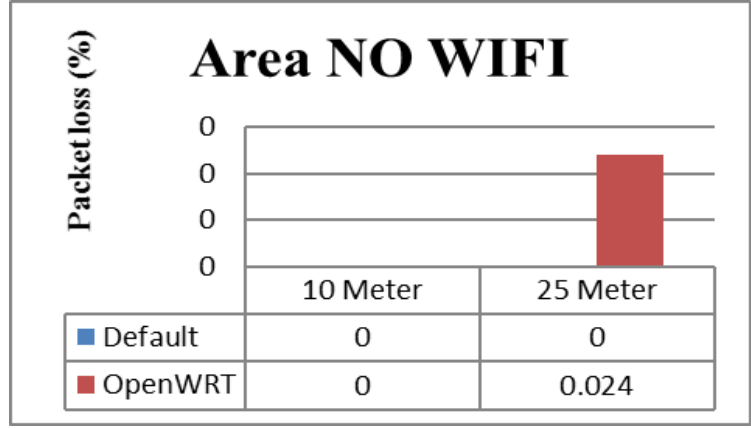

Gambar 9. Pengujian Packet Loss Area NO WIFI

Dari grafik diatas sudah jelas dapat diketahui bahwa hanya terdapat packet loss saat melakukan pengujian pada jarak 25 meter sebesar $0.024 \%$. Hal itu disebabkan karena adanya antrian paket yang panjang dalam pengjian packet loss yang dilakukan yang menyebabkan ada beberapa paket yang tidak samapai pada tujuan.

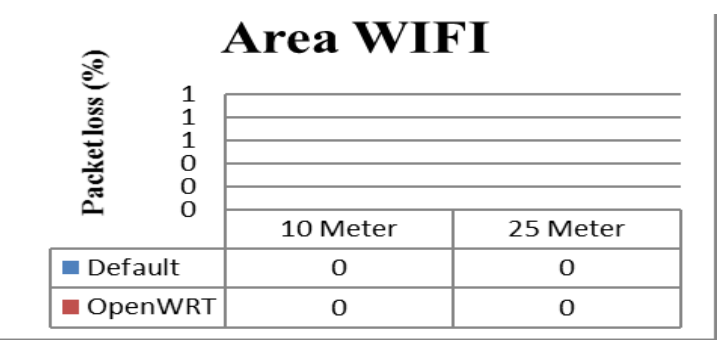

\section{Gambar 10. Pengujian Packet Loss Area WIFI}

Pada pengujian packet loss area WIFI tidak ada perbedaan sama sekali antara Tl-WR841ND yang terpasang Default firmware dan OPenWRT. Kedua firmware tersebut sama-sama menghasilkan packet loss sebesar $0 \%$ baik itu jarak pengujian dengan 10 meter maupun 25 meter.

\section{III.6. Pengujian Delay}

Berikut grafik hasil perbandingan delay Default firmware dengan OpenWRT pada area pengujian NO WIFI dan dengan jarak pengujian 10 dan 25 meter.

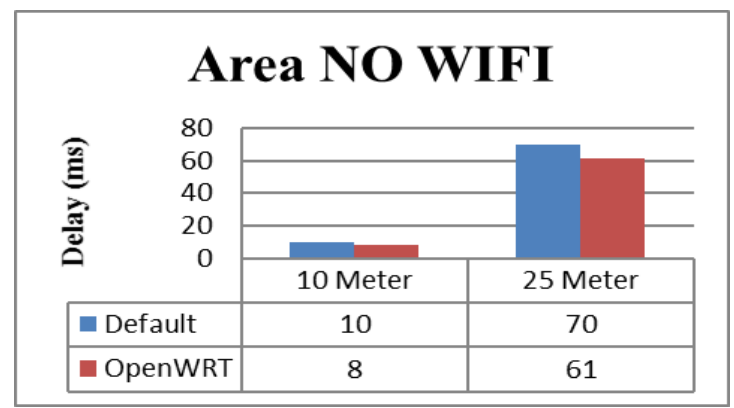

Gambar 11. Pengujian Delay Area NO WIFI 
Pada pengujian yang telah dilakukan pada area NO WIFI didapatkan data delay dimana Default firmware menghasilakan delay yang lebih besar dari pada OpenWRT. Itu berarti delay yang dihasilkan oleh OpenWRT jauh lebih baik dari pada delay yang dihasilkan oleh Default firmware. Selanjutnya pengujian delay yang dilakukan pada area WIFI untuk mengetahui seberapa besar pengaruh interferensi wifi terhadap QoS sebuah jaringan wireless yang dibangun menggunakan wireless routerTl-WR841ND yang terpasang Default firmware dan OpenWRT dapat dilihat pada grafik di gambar 12.

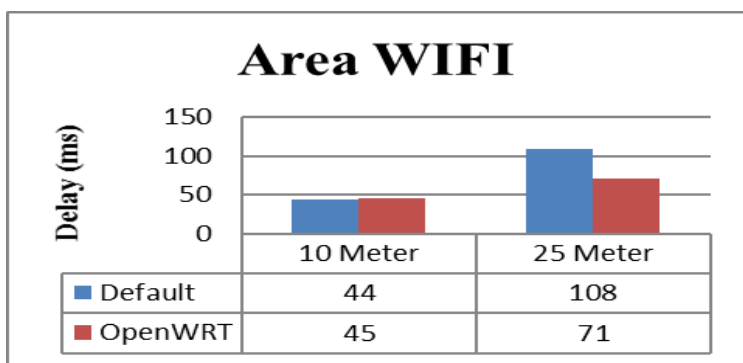

\section{Gambar 12. Pengujian Delay Area WIFI}

Pada area WIFI delay minimum yang didapat selama pengujian sebesar $44 \mathrm{~ms}$, sedangkan pada area NO WIFI delay minimum yang didapat sebesar $8 \mathrm{~ms}$. Pengujian delay yang dilakukan terhadap TL-WR841ND yang terpasang Default firmware pada jarak pengujian 10 meter menghasilkan data delay sebesar $44 \mathrm{~ms}$. Data tersebut lebih kecil $1 \mathrm{~ms}$ dari pengujian yang dilakukan pada OpenWRT pada area dan lokasi yang sama yang sebesar $45 \mathrm{~ms}$. Sedangkan pengujian yang dilakukan pada jarak 25 meter data yang dihasilkan pada Default firmware sebesar 108 ms. Hal itu lebih besar dari data yang didapatkan padaOpenWRT yang sebesar $71 \mathrm{~ms}$ pada jarak dan area yang sama.

\section{III.7 Perbandingan QoS Default Firmware dan OpenWRT}

Pada tahapan ini akan diberikan perbandingan QoS (quality of service) dari Default firmware dan OpenWRT secara keseluruhan, baik itu pada uji throughput, jitter, packet loss, dan delay. Untuk lebih jelas mengenai perbadingan qos yang didapat selama penelitian dapat dilihat pada tabel 5 .

Data tersebut jika ditampilkan dalam versi grafik maka dapat dilihat pada gambar 13 .

Dari data diatas dapat diketahui bahwa sebagian besar Default firmware mendapatkan hasil pengujian yang lebih baik dari pada OpenWRT. Meskipun perbedaan data yang didapat dari keduanya tidak terlalu jauh atau bahkan hampir sama.
Tabel 5. Perbandingan QoS

\begin{tabular}{|c|c|c|c|}
\hline & Default & OpenWRT & Keterangan \\
\hline $\begin{array}{c}\text { Throughput } \\
\text { (Mbit/s) }\end{array}$ & 8.62 & 8.53 & 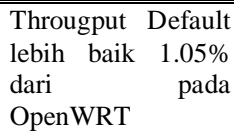 \\
\hline Jitter (ms) & 1.54 & 1.59 & $\begin{array}{l}\text { Jitter Default lebih } \\
\text { baik } 3.24 \% \text { dari } \\
\text { pada OpenWRT }\end{array}$ \\
\hline $\begin{array}{c}\text { Packet Loss } \\
(\%)\end{array}$ & 0 & 0.01 & $\begin{array}{lr}\text { Packet loss } & \text { default } \\
\text { lebih baik } & 0.01 \% \\
\text { dari } & \text { pada } \\
\text { OpenWRT }\end{array}$ \\
\hline Delay (ms) & 54 & 46 & $\begin{array}{l}\text { Delay OpenWRT } \\
\text { lebih baik } 17.39 \% \\
\text { dari pada Default }\end{array}$ \\
\hline
\end{tabular}

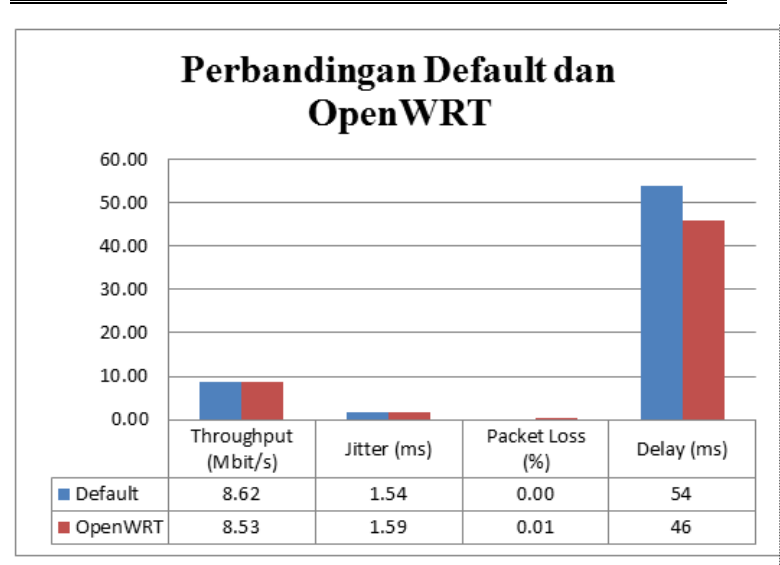

Gambar 13. Perbandingan QoS

\section{KESIMPULAN DAN SARAN}

\section{IV.1 Kesimpulan}

1. Throughput yang didapat dalam pengujian tidak terdapat berbedaan yang jauh atau bahkan hampir sama. TL-WR841ND yang terpasang Default firmware mendapatkan throughput sebesar $8.62 \mathrm{Mbit} / \mathrm{s}$ sedangkan OpenWRT mendapatkan throughput sebesar $8.53 \mathrm{Mbit} / \mathrm{s}$.

Throughput yang didapatkan Default firmware lebih besar $0.09 \mathrm{Mbit} / \mathrm{s}$ atau $1.05 \%$ dari OpenWRT

2. Jitter yang didapatkan oleh Default firmware lebih baik dengan jitter sebesar 1,54 ms. Sedangkan OPenWRT mendapatkan jitter sebesar $1.59 \mathrm{~ms}$. Jitter yang didapatkan Default firmware lebih baik $0.05 \mathrm{~ms}$ atau $3.24 \%$ dari OpenWRT.

3. Jitter yang didapatkan dalam pengujian baik itu pada Default firmware dan OpenWRT menurut standar jitter versi TIPHON masuk ke kategori "BAGUS"

4. Dalam hal packet loss Default firmware mendapatkan data sebesar $0 \%$, yang berarti tidak ada paket yag hilng selama 
pengujian,sedangkan OpenWRT mendapatkan nilai packet loss sebesar $0.01 \%$.

5. Packet loss yang didapat selama pengujian baik itu pada Default firmware dan OpenWRT menurut standar TIPHON masuk ke kategori "BAGUS".

6. Delay yang didapatkan Default firmware selama pengujian lebih buruk dengan delay sebesar $54 \mathrm{~ms}$, sedangkan delay yang didapatkan oleh OpenWRT sebesar $46 \mathrm{~ms}$. Perbedaan delay antara Default firmware dan OpenWRT sebesar $8 \mathrm{~ms}$ atau $17.39 \%$.

7. Delay yang didapat selama pengujian baik itu pada Default firmware dan OpenWRT menurut standar TIPHON masuk ke kategori "SANGAT BAGUS"

\section{IV.2 Saran}

Dari hasil penelitian yang dilakukan, tedapat beberapa saran yang dianggap perlu dipertimbangkan untuk penelitian maupun penggunaan selanjutnya, antara lain:

1. Penelitian ini dapat dikembangkan dengan melakukan konfigurasi lebih details pada wireless router TL-WR841ND baik yang menggunakan default firmware maupun yang menggunakan OpenWRT, jadi peneliti tidak hanya melakukan konfigurasi terhadap $\mathrm{WiFi}$ dan DHCP saja.

2. Penelitian ini juga dapat dikembagkan lagi dengan melakuakn uji perbandingan qos pada infrastruktur keamanan yang digunakan, missal adakah pengaruh penggunaan enkripsi WPA dan WPA2 pada qos jaringan wireless dan adalah perbedaan qos yang signifikan yang terjadi.

3. Penelitian selanjutnya juga bisa dikembangkan dengan melakuka penelitian qos terhadap channel yang digunakan, jadi tidak terfokus hanya pada satu channel saja namun beberapa channel lainnya.

4. Selain itu untuk penelitian berikutnya juga dapat menambahkan pengaruh kinerja wireless router terhadap channel width yang digunakan, apakah lebih baik ketika menggunakan channel 20Mhz atau 40Mhz.

\section{REFERENSI}

Ariyus, Dony dan Rum Andri K.R. 2008. Komunikasi Data. Yogyakarta: Andi

Darmawan, Erristhya. Dkk. 2012. Bandwidth Manajemen Queue Tree vs Simple Queue. Jurnal STMIK STIKOM Bali.

Mulyanta, Edi. 2005. Pengenalan Protokol Jaringan Wireless komputer. Penerbit: ANDI Yogyakarta
Nazir, Moh. (2005). Metodologi Penelitian. Bogor: Ghalia Indonesia.

Russel, Jesse. Cohn, Ronald . 2012. Openwrt. Publish: Book on Demand

Sofyan Yamin dan Heri Kurniawan. 2009. SPSS Complete:Teknik Analisis Statistik Terlengkap Dengan Software SPSS. Jakarta : Salemba Infotek.

Tim Penelitian dan Pengembangan Wahana Komputer, Konsep Jaringan Komputer dan Pengembangan. Jakarta: Salemba Infotek. 